DOI: 10.3157/jpo.v7i2.1173

\title{
PENGEMBANGAN PERMAINAN PAL MIX PEMBELAJARAN PENJASORKES
}

\author{
Yulita $^{1}$, Sukardi $^{2}$ \\ 1.2. Dosen penjaskes, STKIP Melawi \\ 1e-mail: buyulita79@gmail.com
}

\begin{abstract}
Abstrak
Penelitian ini bertujuan untuk menghasilkan model permainan Pal Mixyang dapat digunakan sebagai panduan: 1) mengetahui efektivitas model permainan tradisional Pal Mix 2) mengetahui keterterimaan model permainan tradisional $\mathrm{Pal}$ Mix. Metode penelitian yang digunakan adalah pengembangan produk berupa model permainan Pal Mix untuk siswa SD kelas IV dilakukan dengan tahapan. 1) Pengembangan penelitian deskriftip dan survei, 2) Menyusun desain pruduk, 3) Validasi ahli, 4) Uji coba skala kecil, 5) Menguji produk pengembangan.Hasil penelitian ini berupa permainan Pal Mixyang digunakan sebagai media pembelajaran penjasorkes. Permainan tradisional Pal Mixdalam pembelajaran penjasorkes dapat meningkatkan aspek psikomotor, kognitif dan afektif berdasarkan hasil penelitian yang dilaksanakan di SD yaitu keefektifan produk permainan Pal Mixmendapat respon positif siswa dalam pembelajaran penjasorkes.
\end{abstract}

Kata Kunci:Permainan Tradisional, Pal Mix.

\section{Abstract}

The research aims to produce a Pal Mix game model that can be used as a guide: 1) to know the effectiveness of the Pal Mix traditional game model 2) to know the acceptability of the traditional Pal Mix game model. The research method was product development in the form of Pal Mix game model for grade IV elementary school students conducted by stages. 1) Development of descriptive and survey research, 2) Developing product design, 3) Expert validation, 4) Small-scale trials, 5) Test development products. The results of this study are in the form of Pal Mix which is used as physical education learning media. The traditional Pal Mix game in physical education can improve psychomotor, cognitive and affective aspects. Based on the results of research conducted in elementary school, the effectiveness of Pal Mix game products to get a positive response from students in physical education.

Keywords: Traditional game, Pal Mix

\section{PENDAHULUAN}

Permainan tradisional dikenal memiliki beberapa keunggulan dibanding permainan modern pada masa kini. Permainan tradisional dapat memperkenalkan, melestarikan, sekaligus meningkatkan kecintaan terhadapwarisan budaya bangsa dan nilai-nilai luhur yang terkandung di dalamnya. Pada era globalisasi kini beberapa pakar pendidikan Indonesia berusaha untuk menghidupkan dan melestarikan permainan tradisional di tengah gencarnya pengaruh budaya dan 
teknologi modern, (Pratiwi, 2015). Permainan tradisional adalah salah satu materi yang terdapat pada mata pelajaran penjasorkes yang saat ini sudah mulai ditinggalkan dan jarang dimainkan, anak-anak sekarang beralih ke permainan modern atau canggih seperti playstation, video game, dan game online. Beragam permainan tradisional memang mampu menjadi media untuk mengoptimalkan berbagai kecerdasan kognitif, kecerdasan sosial, kecerdasan musikal, kecerdasan kinestetik, kecerdasan linguistik, kecerdasan spiritual, hingga mengajarkan berbagai nilai positif dan menyehatkan badan (Achroni, 2012: 6). Didalam masyarakat peran penting dalam permainan tradisional, perlu kita kembangkan demi ketahanan budaya bangsa, karena kita menyadari bahwa kebudayaan merupakan nilai-nilai luhur bagi bangsa indonesia, untuk diketahui dan dihayati tata cara kehidupannya sejak dahulu

Pal mix adalah permainan tradisional yang ada di daerah perbatasan Entikong, nama lainnya yaitu kelereng atau Guli. Pal Mixmerupakan satu dari berbagai macam permainan tradisional yang ada di daerah Entikong, permainan ini biasanya dimainkan oleh minimal 2 anak. Namun makin banyak anak yang ikut bermain, permainan akan semakin seru selain itugundu sering dimainkan anak-anak di waktu luang, anak-anak senang bermain gundu .Permainan gundu dapat dilakukan di atas tanah, ubin, permukaan beraspal, atau permukaan semen, gundu identik sebagai mainan anak laki-laki meski begitu gundu bisa dimainkan anak laki-laki maupun perempuan.Buah Pal Mix (campur) adalah permainan Buah Pal dicampur atau digabungkan dengan aktivitas membidik, menyusun potongan puzzle, berlari, melompat, dan melempar.

Alasan pemilihan permainan Buah Pal Mix karenaanak-anak suka dan senang bermain Buah Pal, permainan Buah Pal mix aman dimainkan untuk anakanak, alat-alat yang digunakan relatif murah selain itu Buah Pal mix dikembangkan untuk meningkatkan aspek kognitif, psikomotor, dan afektif serta terciptanya pembelajaran dengan prinsip PAIKEM,

Kecamatan entikong khususnya didaerah perbatasan terdapat17 sekolah dasar Negeri dan 1 Sekolah Dasar Swasta.dengan rincian 3 sekolah dasar yang terakriditasi B yaitu SD Negeri 01 Semanget, SD Negeri 12 Entikong, SDNegeri 
03 Sontasdan 14 sekolah dasar Negeri yang terakriditasi C dan 1, Sekolah Dasar Swasta, data diperoleh dari UPT Kecamatan Entikong

Kelebihan produk Buah PalMix pada pembelajaran penjasorkes untuk siswa SD Antara lain: 1) Menyajikan permainan tradisional Buah PalMix (menyusun puzzle, lari, lempar, dan lompat) yang dikemas secara menarik sehingga siswa sekolah dasar bergerak aktif. 2) Peraturan permainan dan alat-alat yang digunakan di sesuaikan dengan kebutuhan siswa sekolah dasar. 3) Permainan tradisional Buah PalMix aman dimainkan dan alat-alat yang digunakan relatif murah. 4) Pengembangan permainan tradisional Buah Pal Mix dapat membantu guru Penjasorkes dalam proses pembelajaran di sekolah khususnya untuk bahan ajar alternatif dan variasi mengajar pada materi permainan tradisional serta untuk meningkatkan kebugaran jasmani siswa peningkatan dalam setiap ranah tujuan pendidikan yaitu aspek psikomotor, kognitif, dan afektif. Berdasarkan pada uraian di dalam latar belakang masalah, maka penelitian ini dapat dirumuskan permasalahannya yaitu: (1) Permainan Pal Mix efektif dalam pembelajaran penjasorkes untuk siswa SDN Kelas IVKecamatan Entikong?; (2) Permainan Pal Mixdapat diterima dalam pembelajaran penjasorkes untuk siswa SDN Kelas IV Kecamatan Entikong?. Penelitian pengembangan ini bertujuan untuk menghasilkan model permainan tradisional gundu yang dapat digunakan sebagai salah satu cara guru agar tujuan pembelajaran penjasorkes di SDN tercapai.

Penelitian ini diharapkan dapat dijadikan ilmu pengetahuan yang sifatnya informatif guna memberikan kontribusi didalam pembelajaran pendidikan jasmani dan kesehatan. Bagi penulis hasil penelitian ini dapat memperluas wawasan ilmu yang diperoleh dengan kondisi sebenarnya di sekolah.

\section{METODE}

Penelitian pengembangan biasanya disebut pengembangan berbasis penelitian (research-based development) merupakan jenis penelitian yang bertujuan untuk menghasilkan produk baru melalui proses pengembangan. Penelitian pengembangan merupakan jenis penelitian yang digunakan dalam memecahkan persoalan praktis, daam bidang ilmu sosial, ilmu alam, teknik, dan 
dunia pendidikan. Kegiatan penelitian diintegrasikan selama proses pengembangan produk, oleh sebab itu di dalam penelitian ini perlu memadukan beberapa jenis metode penelitian, antara lain jenis penelitian survei dengan eksperimen atau action research dan evaluasi (Multiyaningsih, 2012:161).

Penelitian dan pengembangan adalah suatu proses yang digunakan untuk mengembangkan atau memvalidasi produk-produk yang digunakan dalam pendidikan pembelajaran. (Sugiyono, 2010:407) berpendapat metode penelitian dan pengembangan atau dalam bahasa inggrisnya research and developmenta adalah metode penelitian yang digunakan untuk menghasilkan produk tertentu, dan menguji keefektifan produk tersebut. Melalui penelitian ini diharapkan dapat menjadi variasi penelitian yang lebih banyak menguji teori kearah menghasilkan produk yang dapat digunakan dalam mengembangkan materi permainan tradisional Buah Pal Mix untuk pembelajaran Penjasorkes di SD.

\section{Prosedur Pengembangan}

Rancangan model pengembangan penelitian ini dilakukan dalam enam tahap.Berdasarkan beberapa pendapat tersebut maka prosedur yang digunakan dalam pengembangan model permainan buah Pal Mix untuk pembelajaran penjasorkes di sekolah dasar ini meliputi enam tahap yaitu:

1. Tahap pertama, pengembangan penelitian deskriftip dan survei kepada guru dan siswa SD. Survei bertujuan untuk memperoleh data analisis pelaksanaan pembelajaran permainan tradisional kepada guru dan siswa, persepsi guru dan siswa tentang pembelajaran tradisional di sekolah dasar. Analisis kebutuhan tentang pengembangan materi permainan tradisional melalui Buah Pal Mix di SD.

2. Tahap kedua, langkah penyusunan desain produk awal pengembangan Buah Pal Mix di SD. Validasi materi kepada ahli yang terlibat dalam penelitian antara lain: 1) ahli pendidikan jasmani olahraga dan kesehatan, 2) ahli permainan tradisional, 3) guru penjasorkes. Hasil dari validasi kemudian dikaji untuk memperbaiki rancangan model sebelum diujicobakan.

3. Tahap ketiga, validasi produk kepada ahli yang terlibat dalam penelitian antara lain: 1) ahli pendidikan jasmani olahraga dan kesehatan: 2) ahli 
permainan tradisional: Hasil dari validasi para ahli yang kemudian dikaji untuk memperbaiki rancangan model sebelum diujicobakan.

4. Tahap keempat, uji coba produk pengembangan menggunakan uji coba skala kecil yang melibatkan 3 guru Penjasorkes dan 36 siswa SD kelas IV responden terlebih dahulu. Uji coba skala kecil bermanfaat untuk menganalisis kendala yang mungkin dihadapi dan berusaha untuk mengurangi kendala tersebut pada saat penerapan model berikutnya. Revisi produk pertama dilakukan berdasarkan hasil uji coba produk tahap1.

5. Tahap kelima, melakukan desain penelitian eksperimental yang bertujuan untuk menguji produk pengembangan Buah Pal Mix yang dikembangkan untuk keaktifan, keefektifan pembelajaran, kemenarikan untuk pelaksanaan materi permainan tradisional dalam pembelajaran penjasorkes di SD. Kemudian melakukan uji coba lapangan dengan skala lebih besar yang melibatkan responden yaitu 3 guru Penjasorkes dan 60 siswa SD kelas IV. Revisi produk kedua dilakukan setelah uji coba produk tahap 2.

6. Tahap keenam, penerapan model Buah Pal Mix untuk materi permainan tradisional dalam pembelajaran Penjasorkes di SD, pada tahap ini pengumpulan data dilaksanakan dengan instrumen yaitu berupa kuisioner yang kemudian dilaporkan dan di analisis secara keseluruhan sehingga dapat menyimpulkan untuk keefektifan produk dan terciptanya produk Buah Pal Mixyang sesuai untuk materi permainan tradisional dalam pembelajaran Penjasorkes di SD.

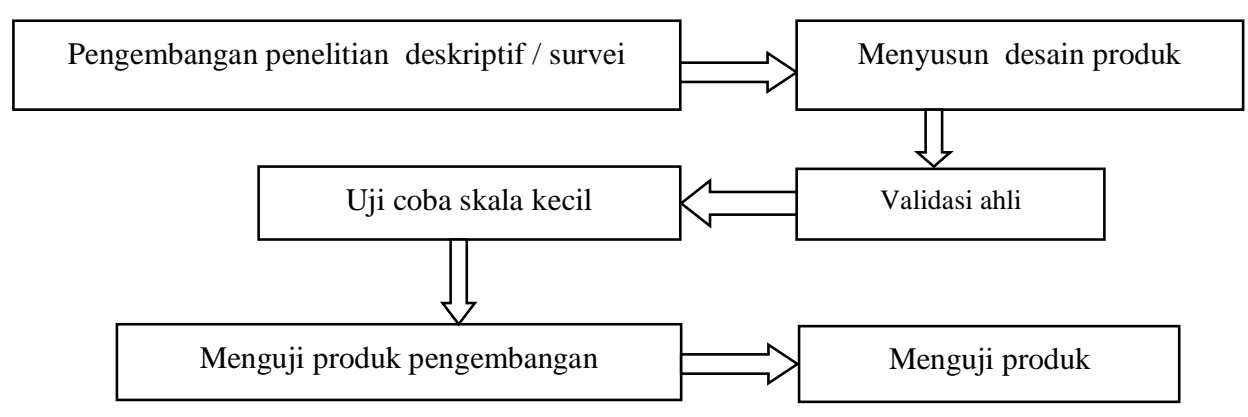

Gambar 1 Langkah-Langkah Pengembangan 


\section{Tehnik Pengumpulan Data}

Metode Pengumpulan data ialah teknik atau cara-cara yang dapat digunakan oleh peneliti untuk mengumpulkan data. Metode (cara atau teknik) menunjuk suatu kata yang abstrak dan tidak diwujudkan dengan benda, tetapi hanya dapat dilihatkan penggunaannya melalui: angket, kuisioner, wawancara pengamatan, ujian (tes), dan dokumentasi (Riduwan, 2007:24). Instrumen dalam penelitian ini adalah kuesioner yang disusun oleh peneliti yang selanjutnya dijadikan alat penilaian dari 2 orang pakar/ahli untuk merevisi produk yang akan dikembangkan. Setelah mendapat persetujuan dari tim ahli (judges) kemudian diujicobakan pada skala kecil untuk dapat mengetahui tingkat validitas dan reliabilitas, selanjutnya dilakukan tes yang sebenarnya pada tes skala besar.

\section{Instrumen Penelitian}

Instrumen yang digunakan dalam pemgembangan produk berupa format untuk ahli permaina tradisional dan ahli penasjorkes, kuesioner, yang berupa kognitif dan rublik, penilaian, psikomotor dan afektif. Kuesioner digunakan untuk mendapatkan atau menjaring dari para ahli maupun guru penjasorkes untuk memberi masukan dan saran serta penilaian tentang kualitas model dan penyediaan sarana prasarana tentang produk yang akan dihasilkan serta kuesioner dari siswa sebagai pengguna produk. Kuesioner yang digunakan guru berupa sejumlah aspek yang harus dinilai kelayakannya.

\section{Teknik Analisis Data}

Penelitian ini bersifat uji coba dan pengembangan model, teknik analisis data yang digunakan adalah dengan menilai tingkat kelayakan, kualitas dan keterimaan produk yang dihasilkan. Model dikatakan efektif apabila pelaksanaan permainan tradisional Buah Pal Mix di sekolah Dasar Kelas IV dapat dilaksanakan di setiap ujicoba dan semua unsur yang terlibat, seperti siswa dan guru dapat melaksanakan model tersebut, selanjutnya model dikatakan efektif, apabila dapat meningkatkan kualitas proses pembelajaran permainanan tradisional Buah Pal Mix Mix untuk siswa Sekolah Dasar kelas IV, dengan indikator model permainan Tradisional Buah Pal Mix Mix bisa membuat anak aktif bergerak, melakukan tugas gerak ketika melakukan permainan Buah Pal Mix, dengan 
ditandai meningkatnya denyut nadi setelah mengikuti pembelajaran permainan Buah Pal Mix .

Analisa data yang digunakan untuk mengetahui keefektifan produk yang telah digunakan oleh siswa, adalah dengan mengetahui peningkatan hasil pengukuran denyut nadi siswa sebelum mengikuti pembelajaran menggunakan (produk).Teknik analisis yang digunakan adalah porsentase untuk menganalisis dan penilaian subyek pengembangan dalam menilai tingkat kelayakan, kualitas dan keterterimaan produk (kegunaan dan relevansi) terhadap produk pengembangan.

\section{Produk Akhir Pengembangan Pal Mix}

Pengembangan permainan tradisional Pal Mix diperlukan tahapan dan revisi yang harus dilakukan sebelum mendapatkan produk akhir. Tahapan revisi yang dilakukan dalam proses pengembangan permainan tradisional Pal Mix, diantaranya adalah perancangan dan penyusunan draf awal permainan tradisionalPal Mix, tahap revisi dan tahap akhir. Berikut ini adalah draf produk akhir pengembangan permainan tradisionalPal Mix.

Pemain di bagi menjadi kelompok/tim, satu kelompok/tim terdiri dari 4-5 pemain, banyaknya kelompok disesuaikan dengan jumlah siswa.Misi dan tujuan dari permainan tradisional Pal mix adalah menyusun potongan puzzle, setiap potongan puzzle didapat dengan cara menyelesaikan setiap pos (Membidik, melempar, dan melompat). Adapun prosedur pelaksanaan permainan tradisional Pal Mix, yaitu:

1. Pos/tugas membidikPal, jika berhasil memasukkan Pal ke kolom warna, pemain mengambil potongan puzzle dan berlari ke pos penyusunan puzzle sambil melakukan tos dengan temannya untuk melakukan pos selanjutnya ketentuan jika Pal masuk ke kolom warna merah muda pemain mendapatkan 1 potongan puzzle, jika $\mathrm{Pal}$ masuk ke kolom warna kuning pemain mendapatkan 2 potongan puzzle, dan jika Pal masuk kekolom warna biru pemain mendapatkan 3 potongan puzzle, jika pada pos membidik pemain gagal maka dilanjutkan pemain lainnya dengan pos yang sama (membidik). 
Pemain yang telah melakukan tugas kembali ke barisan paling belakang untuk menunggu giliran (berlaku untuk setiap pos/tugas).

2. Pos/tugas melempar bola kasti: melempar dengan cara overhead, pemain yang berhasil menjatuhkan cangkir, pemain mengambil potongan puzzle dan berlari ke pos penyusunan puzzle sambil melakukan tos dengan temannya untuk melakukan pos selanjutnya, ketentuan jika 1 cangkir yang jatuh pemain mendapatkan 1 potongan puzzle, jika 2 cangkir yang jatuh pemain mendapatkan 2 potongan puzzle, jika 3 cangkir yang jatuh pemain mendapatkan 3 potongan puzzle.

3. Pos/tugas lompat jauh: pemain melakukan lompatan dengan 2 kaki mendarat, jika pemain berhasil melompat pada kolom warna, pemain mengambil potongan puzzle dan berlari ke pos penyusunan puzzle sambil melakukan tos dengan temannya, ketentuan jika pemain berhasil masuk ke kolom warna merah muda, pemain mendapatkan 1 potongan puzzle, jika pemain masuk ke kolom berwarna kuning, pemain mendapatkan 2 potongan puzzle, dan jika pemain masuk ke kolom warna biru pemain mendapatkan 3 potongan puzzle.

4. Permainan dilakukan secara bergantian setelah melakukan tos dengan temannya.

5. Bagi pemain yang menunggu giliran bertugas mengambilPal, bola kasti, dan menyusun kembali cangkir untuk memulai lagi permainan.

6. Permainan akan berakhir apabila telah ada kelompok/tim yang berhasil mengumpulkan dan menyusun semua potongan-potongan puzzle.

7. Bagi kelompok/tim yang tidak berhasil menyusun potongan-potongan puzzle, harus mengambil kartu tugas yang telah dipersiapkan dan mengikuti isi dari kartu tugas tersebut. 


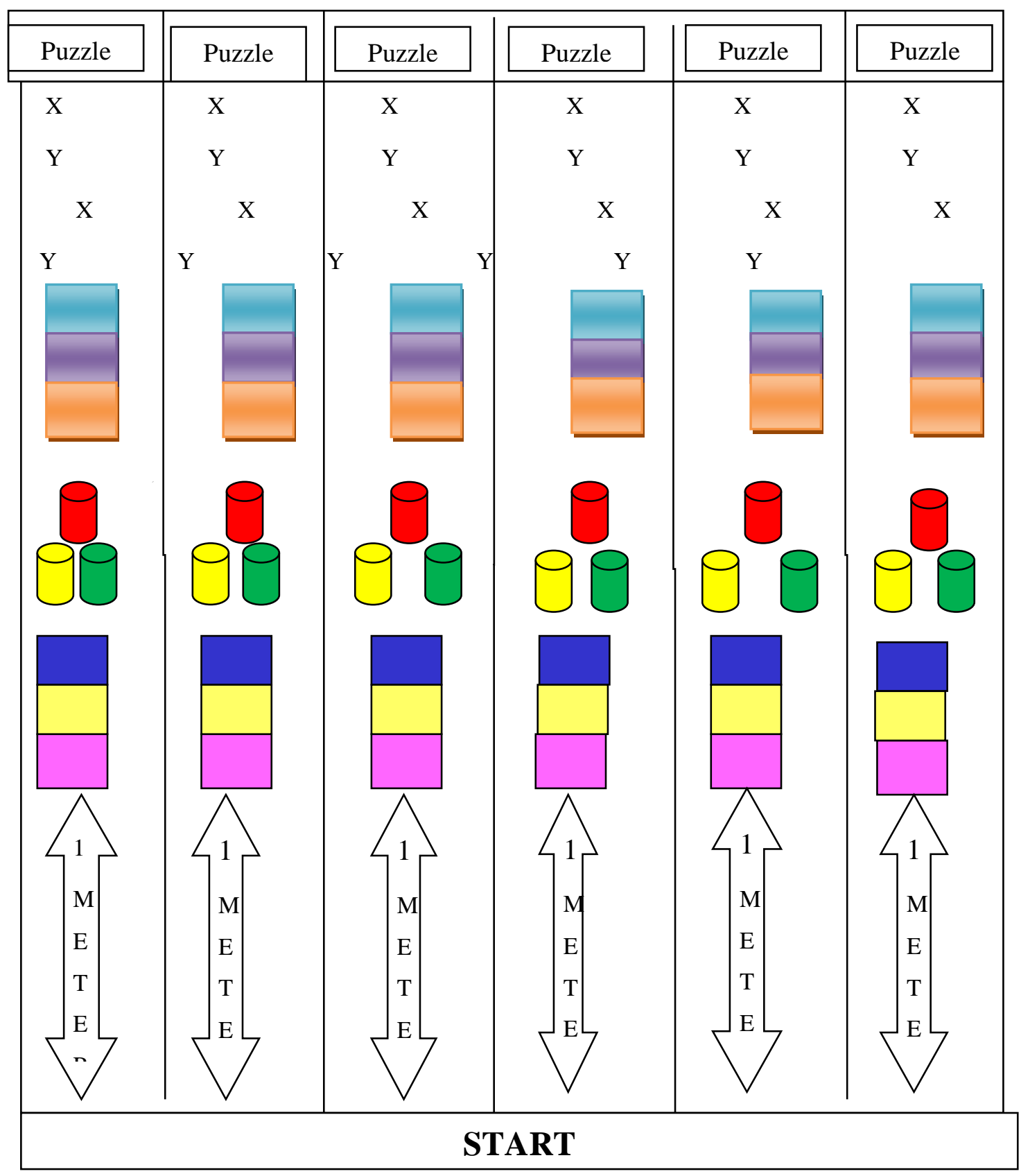

Gambar 2 Lapangan Permainan Tradisonal Pal Mix

Adapun keterangan gambar disajikan pada Tabel 1 berikut. 
Tabel 1 Keterangan Gambar

\begin{tabular}{|c|c|}
\hline Simbol dan Gambar & Keterangan \\
\hline $\mathrm{X}$ & Siswa Putri \\
\hline Y & Siswa Laki-laki \\
\hline$\widehat{\jmath}$ & $\begin{array}{l}\text { Jarak membidik Pal ke sasaran/kolom warna (1 } \\
\text { meter), Jarak lari siswa dari pos melompat menuju } \\
\text { start (3meter) }\end{array}$ \\
\hline & $\begin{array}{l}\text { Kolom sasaran membidikPal pada pos satu dibuat } \\
\text { menggunakan kapur berwarna (PxL=50x50 } \\
\mathrm{cm} \text { ),hijau dapat } 3 \text { potongan puzzle, ungu dapat } 2 \\
\text { potongan puzzle, dan orange dapat } 1 \text { potongan } \\
\text { puzzle. }\end{array}$ \\
\hline & $\begin{array}{lll}\text { Cangkir Plastik yang di isi batu koral pada pos } \\
\text { dua,apabila jatuh } 1 \text { cangkir mendapatkan } & 1 \\
\text { potongan puzzle, } 2 \text { cangkir mendapatkan } & 2 \\
\text { potongan puzzle, } 3 \text { cangkir mendapatkan } & 3 \\
\text { potongan puzzle } & & \end{array}$ \\
\hline & $\begin{array}{l}\text { Kolom lompatan pada pos tiga dibuat menggunakan } \\
\text { kapur berwarna }(\mathrm{PxL}=50 \times 50 \mathrm{~cm}) \text { biru dapat } \\
\text { 3potongan puzzle, kuning dapat } 2 \text { potongan } \text { Puzzle, } \\
\text { dan merah muda dapat } 1 \text { potongan puzzle }\end{array}$ \\
\hline Puzzle & $\begin{array}{l}\text { Jarak Pos penyusun puzzle } 10 \text { meter dari Pos } \\
\text { lompatan, terdapat } 28 \text { potongan puzzle }\end{array}$ \\
\hline
\end{tabular}

\section{HASIL DAN PEMBAHASAN}

Data responden guru Penjasorkes sebagai penguat dalam penyebaran kuesioner yang diambil datanya maka terdapat respon positif dan negatif. Hasil pengisian angket respon terhadap guru dianalisis dengan dipersentasekan dan diperoleh bahwa 92,5\% atau guru penjasorkes memberikan respon positif dan 7,5\% memberikan respon negatifberarti guru penjasorkes yang memberikan respon positif lebih dari $81 \%$ maka dapat dikategorikan bahwa respon guru penjasorkes terhadap pengembangan $\mathrm{Pal}$ Mix sebagai alternatif pembelajaran penjasorkes tergolong positif. 
Tabel 2 Data Penyebaran Aspek Kognitif, Psikomotor dan Afektif

\begin{tabular}{lcccccc}
\hline Aspek & $\begin{array}{c}\text { Jumlah } \\
\text { Siswa }\end{array}$ & $\begin{array}{c}\text { Nilai } \\
\text { Maksimal }\end{array}$ & $\begin{array}{c}\text { Jumlah } \\
\text { Positif }\end{array}$ & $\begin{array}{c}\text { Jumlah } \\
\text { Negatif }\end{array}$ & \% Positif & \% Negatif \\
\hline Kognitif & 60 & 10 & 640 & 60 & 91,42 & 8.58 \\
\hline Psikimotor & 60 & 16 & 1092 & 28 & 93,5 & 6,5 \\
\hline Afektif & 60 & 10 & 665 & 35 & 95,25 & 4,75 \\
\hline
\end{tabular}

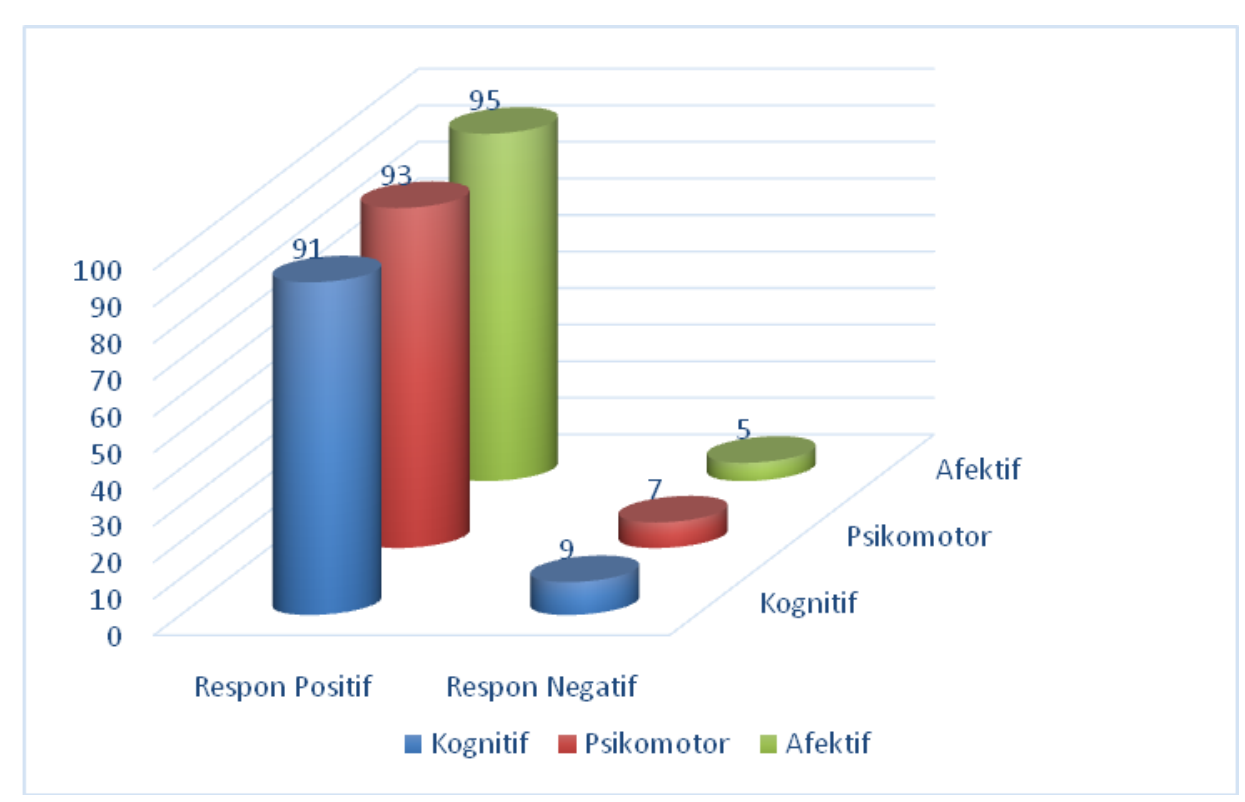

Gambar 2 Grafik Peniilaian Psikomotor, kognitif dan Afektif

Data responden siswa sebagai penguat dalam penilaian yang diambil dengan indikator kognitif respon positif sebesar 91,42\%, respon negatif sebesar $8,58 \%$. Indikator psikomotor respon positif sebesar 93,5\%, respon negatif sebesar $6,5 \%$. Indikator afektif respon positif sebesar 95,25\%, respon negatif sebesar 4,75\%. Data secara lengkap ada pada lampiran.

Penghitungan indikator kognitif koefisien reliabilitas menggunakan Guttman Split-Half Coefficient untuk 60 siswa sebagai responden yaitu 0,588. Dapat disimpulkan hasil reliabilitas untuk respon siswa dikatakan reliabel karena rhitung lebih besar dari $r$ tabel yaitu 0,245 dengan taraf signifikan 5\%.Penghitungan koefisien reliabilitas menggunakan Guttman Split-Half Coefficientuntuk 60 siswa sebagai responden yaitu 0,546. Dapat disimpulkan hasil reliabilitas untuk respon siswa dikatakan reliabel karena $\mathrm{r}_{\text {hitung }}$ lebih besar dari $r_{\text {tabel }}$ yaitu 0,236 dengan taraf signifikan 5\%. 
Penghitungan indikator psikomotor koefisien reliabilitas menggunakan Guttman Split-Half Coefficient untuk 60 siswa sebagai responden yaitu 0,546. Dapat disimpulkan hasil reliabilitas untuk respon siswa dikatakan reliabel karena $\mathrm{r}_{\text {hitung }}$ lebih besar dari $\mathrm{r}_{\text {tabel }}$ yaitu 0,236 dengan taraf signifikan $5 \%$.

Penghitungan indikator afektif koefisien reliabilitas menggunakan Guttman Split-Half Coefficient untuk 60 siswa sebagai responden yaitu 0,545. Dapat disimpulkan hasil reliabilitas untuk respon siswa dikatakan reliabel karena $r_{\text {hitung }}$ lebih besar dari $r_{\text {tabel }}$ yaitu 0,235 dengan taraf signifikan 5\%.

\section{Pembahasan}

Permainan Tradisional Pal Mix di kemas secara menarik yang di dalamnya terdapat unsur (menyusun puzzle, lari, lempar, dan lompat)agar siswa sekolah dasar bergerak aktif. Peraturan permainan dan alat-alat yang digunakan di sesuaikan dengan kebutuhan siswa sekolah dasar.Permainan tradisional Pal Mix aman dimainkan dan alat-alat yang digunakan relatif murah.Pengembangan permainan tradisional Pal Mix dapat membantu guru Penjasorkes dalam proses pembelajaran di sekolah khususnya untuk bahan ajar alternatif dan variasi mengajar pada materi permainan tradisional serta untuk meningkatkan kebugaran jasmani siswa peningkatan dalam setiap ranah tujuan pendidikan yaitu aspek psikomotor, kognitif, dan afektif.

Berdasarkan langkah-langkah penelitian pengembangan untuk menghasilkan produk yang telah dilakukan, maka di dapat produk akhir berupa model permainan tradisional Pal Mix yang sesuai dengan karakterisitik siswa sekolah dasar. Indikator keberhasilan produk ini ialah berupa lembar penilaian hasil pengamatan terhadap seluruh subyek yang diujicobakan dalam penelitian ini.penghitungan uji coba skala luas keterterimaan produk terhadap 60 siswa hasil akhir respon positif termotivasinya siswa dalam permainan tradisional Pal Mix hal ini dapat diartikan bahwa sangat positif keterterimaan permainan tradisional Pal Mix sebagai pembelajaranyangmenarik, menyenangkan dan juga sebagai bahan ajar alternatif guru penjasorkes dalam pelaksanaan pembelajaran penjasorkes di sekolah terutama untuk siswa kelas IV SD dengan bukti hasil dari kuisioner yang dibagikan kepada 2 guru penjasorkes. 


\section{Simpulan}

Berdasarkan hasil penelitian dan pembahasan tentang pengembangan permainan tradisioanl Pal Mix untuk pembelajaran penjasorkes di SD, maka dapat disimpulkan sebagai berikut:1) Permainan tradisional Pal Mix dalam pembelajaran penjasorkes dapat meningkatkan aspek psikomotor, kognitif dan afektif berdasarkan hasil penelitian yang dilaksanakan di 2 SD yaitu keefektifan produk permainan tradisioanl Pal Mix mendapat respon positif siswa dalam pembelajaran penjasorkes sebesar $95,25 \%$ sedang respon negative sebesar 3,75\%. Jadi kesimpulan keefektifan produk permainan tradisional Pal Mix dalam kategori sangat baik. 2) Permainan tradisional Pal Mix dalam pembelajaran penjasorkes dapat dijadikan sebagai bahan alternatif guru dalam pelaksanaan pembelajaran berdasarkan hasil penelitian yang dilaksanakan di 2 SD yaitu hasil pengisian angket respon terhadap guru dianalisis dengan dipersentasekan dan diperoleh bahwa 92,5\% guru Penjasorkes memberikan respon positif dan 7,5\% memberikan respon negatif berarti guru Penjasorkes yang memberikan respon positif lebih dari $81 \%$ maka dapat dikategorikan bahwa respon guru Penjasorkes terhadap pengembangan permainan tradisional Pal Mix sebagai alternatif pembelajaran dalam kategori sangat baik.

\section{DAFTAR PUSTAKA}

Achroni, K. 2012. Mengoptimalkan Tumbuh Kembang Anak Melalui Permainan Tradisional. Yogyakarta: Javalitera.

Mulyatiningsih, Endang. 2012. Metode Penelitian Terapan Bidang Pendidikan. Bandung: Alfabeta.

Pratiwi Yhana. 2015 .Upaya Meningkatkan Kemampuan Motorik Kasar (Keseimbangan Tubuh) Anak Melalui Permainan Tradisional Engklek Di Kelompok B Tunas Rimba Ii Tahun Ajaran 2014/2015. Jurnal Penelitian PAUDIA

Riduwan. 2010. Skala Pengukuran Variabel-Variabel Penelitian. Cet 7. Bandung: Alfabeta.

Sugiyono. 2010. Metode Penelitian Pendidikan. Bandung: Alfabeta.

Sutrisno, H. 2004. Metodelogi Research Jilid 2. Yogyakarta: Andi Offset. 